\title{
Actinopterygii, Siluriformes, Loricariidae, Hypostomus aspilogaster (Cope, 1894). Distribution extension and first record for Argentina
}

\author{
Yamila P. Cardoso ${ }^{1 *}$, Florencia Brancolini ${ }^{2}$, Lucila Protogino ${ }^{3}$ and Marta Lizarralde ${ }^{1}$ \\ 1 Consejo Nacional de Investigaciones Científicas y Técnicas (CONICET), Centro Regional de Estudios Genómicos (CREG), Avenida Calchaquí Km \\ 23,5, Florencio Varela, C.C. 1888, BA, Argentina. \\ 2 Instituto de Limnología “Dr. Raúl A. Ringuelet” (UNLP-CONICET-CCT La Plata), C.C. 712, 1900 La Plata, BA, Argentina. \\ 3 Consejo Nacional de Investigaciones Científicas y Técnicas (CONICET), Instituto de Limnología “Dr. Raúl A. Ringuelet” (CONICET-CCT La Plata). \\ C.C. 712, 1900 La Plata, BA, Argentina. \\ * Corresponding author. E-mail: yamilapcardoso@gmail.com
}

\begin{abstract}
The present work extends to Argentina the distribution of Hypostomus aspilogaster originally described from Uruguay River in southern Brazil. The examined specimens were sampled in the stream Mandisoví Grande, affluent of Uruguay River in Entre Ríos province, and in Punta Lara, from Río de la Plata basin, in Buenos Aires province, Argentina. This represents the first country record for this species.
\end{abstract}

Among the Siluriformes, the Loricariidae family is one of the most diverse in number of genera and species in the Neotropical Region and comprises seven subfamilies (Chiachio et al. 2008). In the subfamily Hypostominae, the genus Hypostomus Lacépède, 1803 includes approximately 130 species. This genus constitutes an assemblage of bottom-dwelling fishes with algivorous or detritivorous habits. Hypostomus are found in lentic and lotic freshwater environments. The wide distribution range of this genus covers from Colombia to Salado River basin in Buenos Aires province, Argentina (López and Miquelarena 1991; Ferraris 2007).

The species Hypostomus aspilogaster (Cope, 1894) was originally described from Jacui River in Rio Grande do Sul, Brazil. Cope (1894) mentioned for this species that: "the scuta are not keeled, but are distinctly angular on the dorsolateral and ventrolateral rows, and traces of keels exist on the anterior scuta of the two median lateral rows". Later, Reis et al. (1990) in the review of the Hypostomus genus, proposed the following diagnostic characters of $H$. aspilogaster: larger number of lateral scutes 29-31, 3-5 scutes bordering the posterior margin of the supraoccipital bone and longer lower caudal fin spine (3.0-3.5 in standard length).

The specimens examined in this work were collected in the stream Mandisoví Grande, tributary of Uruguay River, Entre Ríos province and Punta Lara, Río de la Plata basin, Buenos Aires province, Argentina (Figure 1). The permissions to collect fish were given by Ministerio de Asuntos Agrarios, Buenos Aires province (MAA N79) and Dirección de Recursos Naturales, Ministerio de Producción, Entre Ríos province. Fish specimens (Figure 2), were fixed in formalin and then in ethanol $70 \%$ and are deposited at Instituto de Limnología "Dr. Raúl A. Ringuelet" (Institutional Code: ILPLA).Tissue sampling for molecular analyses was performed in the field. Tissues were fixed in ethanol 96\%. Details on the material examined can be found in Appendix 1.

Morphology measurements and counts follow Reis et al., (1990), see Table 1. All measurements were taken point to point with digital calipers Digimess to the nearest $0.1 \mathrm{~mm}$. Moreover, for two specimens (one of each locality sampled), we performed molecular analysis. DNA was extracted using the salt-extraction protocol (Aljanabi and Martinez 1997). The PCR amplification of the D-loop or control region of the mitochondrial DNA was performed using the following primers: DLA-III 5'-TATTTAAAGRCATAATCTCTTGAC-3' and HygDL-R 5'WTGCKARTATGTGCCGYYTG-3'. The PCR products were

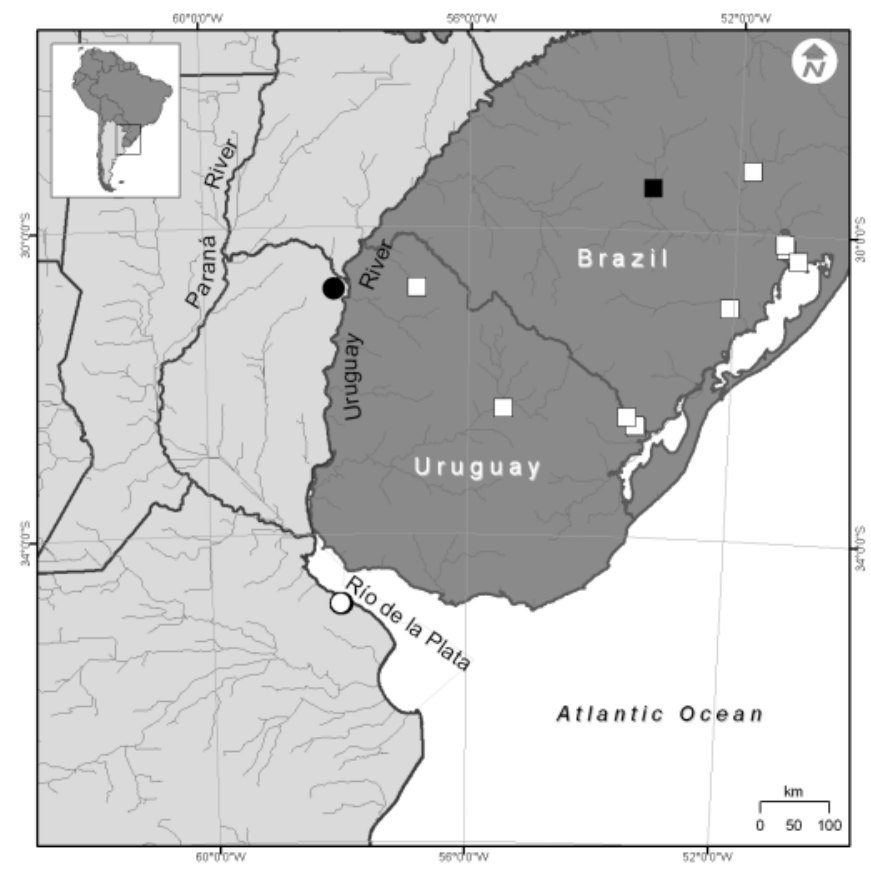

FIGURE 1. Hypostomus aspilogaster distribution: black square: type locality; white square: localities cited in Reis et al. 1990; black circle: stream Mandisoví Grande, Entre Ríos province, Argentina; white circle: Punta Lara, Buenos Aires province, Argentina. 
purified and sequenced in MAGROGEN Korea. The DNA sequences were edited and aligned using the BioEdit 7.0.1 program (Hall 1999). The sequences obtained were analyzed with other 28 sequences of Hypostomus genus deposited in GenBank. Among these 28 sequences, we used a sequence of $H$. aspilogaster from the type locality. This allows us to infer the phylogenies of Hypostomus genus using the Maximum Likelihood method with the TreeFinder program (Jobb et al. 2004).

The molecular results (Figure 3) show that the sequences of the specimens collected in Uruguay and
Río de la Plata rivers, Argentina, and the sequences of $H$. aspilogaster from the type locality are a monophyletic group.

An analysis which makes up molecular, morphometric and meristic data represents an invaluable tool for clarifying the systematics of complex groups on which, at the moment, we do not have complete knowledge. As an outcome of this integrated analysis, we allow to extend the distribution of $H$. aspilogaster in the Neotropical Region and present the first record of this species in Argentina.
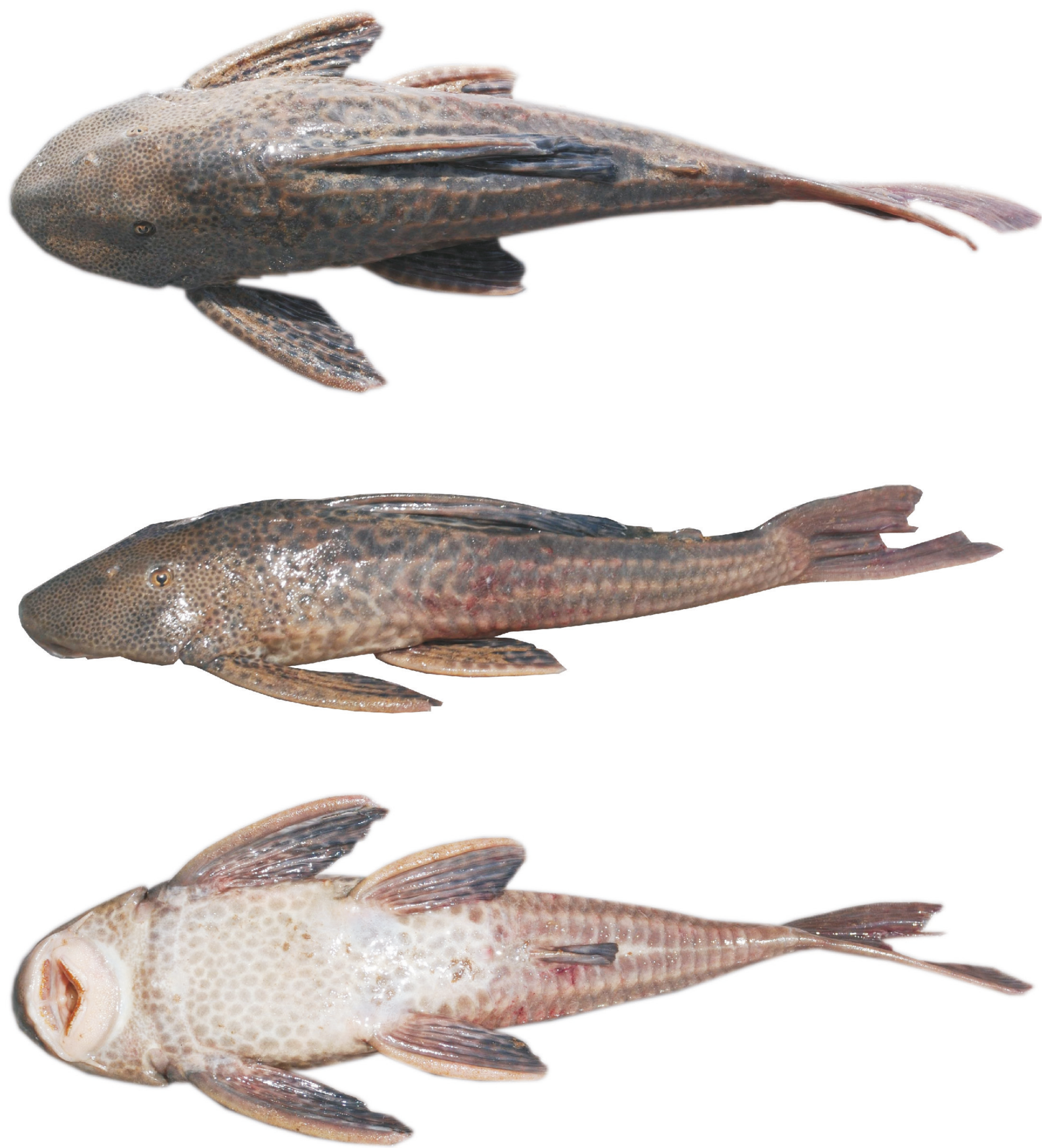

FiguRE 2. Dorsal, lateral and ventral views of a live specimen of Hypostomus aspilogaster collected in the stream Mandisoví Grande, Entre Ríos province, Argentina. ILPLA 2156, (YC09-090), 285.2 mm SL. 


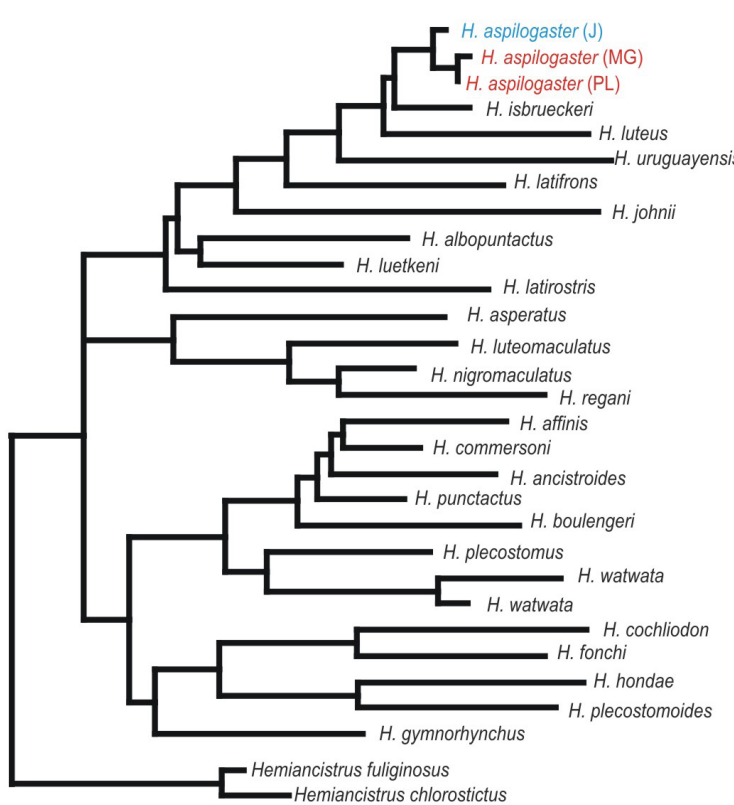

FIGURE 3. Hypostomus phylogenetic tree, based in D-loop mitochondrial marker; H. aspilogaster from type locality Rio Jacui, Brazil (J); stream Mandisoví Grande, Argentina (MG) and Punta Lara, Argentina (PL).

ACKNOWLEDGMENTS: The authors wish to thank to CONICET and Montoya-Burgos for the financial support. We are grateful to Roberto E. Reis (MCP) for his useful photography comments. Thanks are also due to Diego Barrasso and Javier Negrete for helping in the field trip in Entre Ríos province.

\section{LITERATURE CITED}

Aljanabi, S.M. and I. Martinez. 1997. Universal and rapid salt-extraction of high quality genomic DNA for PCR-based techniques. Nucleic Acids Research 25: 4692-4693.

Chiachio, M.C., C. Oliveira and J.I. Montoya-Burgos. 2008. Molecular systematic and historical biogeography of the armored Neotropical catfishes Hypoptopomatimae and Neoplecostominae (Siluriformes: Loricariidae). Molecular Phygenetics and Evolution 49: 606-617.

Cope, E.D. 1894. On the fishes obtained by the naturalist expedition in Rio Grande do Sul. Proceeding of the American Philosophical Society 33(144): 84-108.

Ferraris, C.J.Jr. 2007. Checklist of catfishes, recent and fossil (Osteichthyes: Siluriformes), and catalogue of siluriform primary types. Zootaxa 1418: 1-628.

Hall, T. 1999. BioEdit: a user-friendly biological sequence alignment editor and analysis program for Windows 95/98/NT. Nucleic Acid Symposium Series 41: 95-98.

Jobb, G., A. von Haeseler and K. Strimmer. 2004. TreeFinder: a powerful graphical analysis environment for molecular phylogenetics. BMC Evolutionary Biology 4: 18.

López, H.L. and A. Miquelarena. 1991. Los Hypostominae (Pisces: Loricariidae) de Argentina. Programa de Fauna de Agua Dulce Museo de La Plata. La Plata. Argentina 40(2): 1-64.

Reis, R.E., C. Weber and L.H. Malabarba. 1990. Review of the genus Hypostomus Lacépède, 1803 from Southern Brazil, with descriptions of three new species (Pisces, Siluriformes, Loricariidae). Revue suisse Zoology 97(3): 729-766.

RECEIVED: May 2011

LAST REVISED: August 2011

ACCEPTED: August 2011

PUBLISHED ONLINE: September 2011

EDITORIAL RESPONSIBILITY: Sergio Maia Queiroz Lima
TABLE 1. Morphometric and meristic data of Hypostomus aspilogaster $(\mathrm{n}=$ 4) from Argentina.

\begin{tabular}{lcccc}
\hline \multicolumn{1}{c}{ CHARACTER } & LOW & HIGH & MEAN & SD \\
\hline Standard length (mm) & 281.2 & 395.0 & 333.6 & 58.89 \\
Predorsal distance & 2.6 & 2.9 & 2.8 & 0.13 \\
Cleithral width & 3.5 & 3.9 & 3.7 & 0.19 \\
Head length & 3.5 & 3.6 & 3.6 & 0.05 \\
Length of dorsal fin spine & 3.2 & 3.6 & 3.3 & 0.21 \\
Length of dorsal fin base & 3.6 & 3.9 & 3.8 & 0.11 \\
Dorsal base to adipose spine & 4.2 & 5.3 & 4.8 & 0.44 \\
Pectoral fin spine length & 3.2 & 3.4 & 3.3 & 0.09 \\
Pelvic fin spine length & 4.0 & 4.2 & 4.1 & 0.10 \\
Trunk length & 4.2 & 4.5 & 4.4 & 0.12 \\
Abdominal length & 4.2 & 4.6 & 4.4 & 0.19 \\
Caudal peduncle length & 3.1 & 3.1 & 3.1 & 0.03 \\
Caudal peduncle depth & 10.9 & 11.8 & 11.3 & 0.39 \\
Adipose fin spine length & 16.7 & 23.0 & 20.1 & 3.22 \\
Upper caudal ray length & 3.8 & 3.9 & 3.9 & 0.09 \\
Lower caudal ray length & 3.1 & 4.1 & 3.5 & 0.46 \\
\hline Head length & & & & \\
\hline Head depth & 1.5 & 1.6 & 1.5 & 0.06 \\
Snout length & 1.5 & 1.7 & 1.6 & 0.08 \\
Least interorbital width & 2.7 & 2.7 & 2.7 & 0.04 \\
Horizontal eye diameter & 8.2 & 10.0 & 9.0 & 0.84 \\
Rictal barbel & 7.5 & 11.0 & 8.8 & 1.53 \\
Right mandibular ramus & 4.8 & 6.3 & 5.6 & 0.68 \\
\hline Counts & & & & \\
\hline Series of lateral scutes & 30 & 30 & 30 & 0.00 \\
Predorsal scutes & 3 & 4 & 4 & 0.58 \\
Scutes at dorsal fin base & 9 & 10 & 10 & 0.50 \\
Dorsal to adipose fin scutes & 9 & 9 & 9 & 0.00 \\
Adipose to caudal fin scutes & 5 & 6 & 6 & 0.50 \\
Scutes at anal fin base & 3 & 3 & 3 & 0.00 \\
Anal to caudal fin scutes & 14 & 16 & 15 & 0.96 \\
Teeth on left premaxilla & 30 & 36 & 33 & 3.00 \\
Teeth on right premaxilla & 33 & 44 & 39 & 4.86 \\
Teeth on left dentary & 34 & 50 & 43 & 8.06 \\
Teeth on right dentary & 35 & 43 & 40 & 3.40 \\
Plates bordering supraoccipital & 4 & 4 & 4 & 0.00 \\
\hline & & & & \\
\hline
\end{tabular}

APPENDIX 1. Museum records of species analyzed. ILPLA: Instituto de Limnología "Dr. Raúl A. Ringuelet" (CONICET-UNLP), La Plata, Buenos Aires province, Argentina.

Hypostomus aspilogaster: Argentina: ILPLA 2154 (YC09-011), 395.0 mm SL, Buenos Aires province, Punta Lara, Río de la Plata basin, 3446'23.44" S, 5759'14.04" W, Col. Fisherman, 01/09/09; ILPLA 2155 (YC09082), $372.9 \mathrm{~mm}$ SL, Buenos Aires province, Punta Lara, Río de la Plata basin, 3445'47.8” S, 5759'9.14" W, Col. Fisherman, 22/09/09; ILPLA 2156 (YC09-089,YC09-090), 281.2-285.2 mm SL, Entre Ríos province, stream Mandisoví Grande, Federación department, Uruguay River basin, 3053'50.64" S, 5802'34.92" W, Col. Y.P. Cardoso, D. Barrasso and J. Negrete, 10/11/09. 